\title{
INSECTICIDAL EFFECTS OF ANTARCTIC ALGAE Prasiola crispa EXTRACT IN THE ADULT FRUIT FLY Drosophila melanogaster
}

http://dx.doi.org/10.4322/apa.2014.027

\section{Thaís Posser ${ }^{1, *}$, Betina Kappel Pereira², Ana Paula Pegoraro Zemolin, Cháriston André Dal Belo, Antonio Batista Pereira ${ }^{3}$, Jeferson Luis Franco ${ }^{1}$}

\author{
${ }^{1}$ Centro Interdisciplinar de Pesquisas em Biotecnologia, Universidade Federal do Pampa -UNIPAMPA, São Gabriel, RS, Brazi \\ ${ }^{2}$ Colégio Cristo Redentor, Universidade Luterana do Brasil -ULBRA, Canoas, RS, Brasil \\ ${ }^{3}$ Universidade Federal do Pampa -UNIPAMPA, São Gabriel, RS, Brazil \\ *e-mail: thaisposser@unipampa.edu.br
}

\begin{abstract}
In the present study, we aimed to investigate the toxic effects of Prasiola crispa extract on a fruit fly (Drosophila melanogaster) model. Toxicity was assessed as \% mortality, negative geotaxis behaviour and acetylcholine esterase (AchE), glutathione S-transferase (GST), catalase (CAT) activities as well as glutathione content (GSH) and hydroperoxide formation. Administration of algae extract $(2 \mathrm{mg} / \mathrm{mL})$ to flies for 24 hours resulted in a massive increase in mortality (7.6 fold increase, compared to control). A significant increase in climbing performance, indicating an alteration in negative geotaxis behaviour, was also observed. The AchE activity was unchanged after algae extract treatment for 24 hours. However, GST activity was significantly increased after Prasiola crispa administration. The CAT activity was significantly diminished in flies that received algae extract for 24 hours. Glutathione levels and hydroperoxide formation remained unchanged. Our results show for the first time the toxic effects of an Antarctic algae extract in Drosophila melanogaster. The insecticide action of Prasiola crispa may be related to changes on vital antioxidant systems. Further studies are necessary to elucidate the exact mechanisms of toxicity of this Antarctic alga to Drosophila melanogaster.
\end{abstract}

Keywords: Prasiola crispa, toxicity, Drosophila melanogaster, Antarctica

\section{Introduction}

The insecticidal properties of a number of plants have been investigated for thousands of years, and some of the plants can substitute many synthetic means of control (Sujatha, 2010). In this respect, it is important to emphasize that natural agents are environmentally less harmful than synthetic pesticides. Moreover, natural agents can act in many insects in different ways (Sujatha, 2010).

Prasiola crispa is a terrestrial eukaryotic green alga from Antarctica continent. Although there are no studies targeting the biological effects of this algae, interesting characteristics, like adhesive properties has been described for plant of the genus Prasiola sp. (Mostaert et al., 2006), highlighting the biotechnological importance of this organism. A study carried out with three Antarctic plant species (Deschampsia antarctica Desv., Colobanthus quitensis (Kunth) Bartl., and Polytrichum juniperinum Hedw), have demonstrated low toxic effects for mammalian and nonmammalian cells, associated with protective effects against UV-induced damage (Pereira et al., 2009).

It has been recognized that organisms living in Polar Regions, are subject to extreme environmental conditions. This fact has led to the development of natural strategies 
that enable the survival of these organisms under the most extreme environmental conditions on Earth. Among these strategies of adaptation is the production of photoprotective compounds, such as mycosporine-like amino acids, scytonemim secreted by cyanobacteria and flavonoids secreted by plants (Pereira et al., 2009). This fact emphasizes the importance of studies concerning the biological effects of these organisms, which may present in its constitution a combination of chemical compounds normally not found in other organisms.

In this respect, the main aim of this study was to evaluate the effects of the extract of the terrestrial eukaryotic green alga from Antarctica, Prasiola crispa on survival of adult $D$. melanogaster, and in parallel, to verify a possible modulation of antioxidant enzymes activity and locomotor performance in response to the exposure of this organism to the Prasiola crispa extract. The fruit fly Drosophila melanogaster, belongs to the order Diptera and family Drosophilidae. This model is recognized for its high sensitivity to toxic substances, thus being considered a bioindicator for detection of pollutants and also to test the biological action of natural substances.

\section{Materials and Methods}

\section{Plant material}

Prasiola crispa (Lightfoot) Kützing (1843) was collected in the ice-free areas near Arctowski Polish Base Region, Admiralty Bay, King George Island (61 $50^{\prime}-62^{\circ} 15^{\prime} \mathrm{S}$ and $\left.57^{\circ} 30^{\prime}-59^{\circ} 00^{\prime} \mathrm{W}\right)$, Antarctica. The plants were dried in a dark chamber with circulating air at $40{ }^{\circ} \mathrm{C}$ and stored in dark bags in a freezer. The dried and powdered plant material (about $100 \mathrm{~g}$ ) was submitted to extraction using methanol (powder/solvent ratio $=1: 10 \mathrm{w} / \mathrm{v}$ ) by maceration at room temperature. After 24 hours of extraction the sample was filtered through Whatman number 1 filter paper and the same plant material was extracted again with another $1000 \mathrm{~mL}$ of methanol. This procedure was repeated for 3 days, after which the methanolic solutions were combined and evaporated to dryness under reduced pressure by rotary evaporator at $40-50{ }^{\circ} \mathrm{C}$ to obtain the methanolic extracts.

\section{Drosophila culture and Prasiola crispa extract treatment}

Flies were maintained at $25{ }^{\circ} \mathrm{C}$ on a standard diet (Golombieski et al., 2008). For P. crispa extract exposition experiments, 60 male adult flies were placed in a vial containing cotton wool soaked in $2 \mathrm{M}$ sucrose with or without dissolved Prasiola crispa extract $(2 \mathrm{mg} / \mathrm{mL})$. The flies were maintained under these conditions up to 24 hours. Finished the period of treatment, 15 individual flies were submitted to behavioural test and a total of 45 flies were homogenized for biochemical analysis. Each experiment was repeated 3 times using different fly cultures.

\section{Flies mortality}

Finished the treatments, the number of dead flies were counted and plotted as percent of total flies.

\section{Negative geotaxis and response to flight test}

Locomotor ability was determined though the negative geotaxis assay as described by Bland et al. (2009), with some modifications. For the assays, 15 adult flies were anesthetized and placed separately in a vertical glass column (length, $25 \mathrm{~cm}$; diameter, $1.5 \mathrm{~cm}$ ) (Jimenez-Del-Rio et al., 2010). The assays were repeated three times at 1 minute intervals. After 30 minutes recovery, individual flies were gently tapped to the bottom of the column and the time required to reach $8 \mathrm{~cm}$ in the columns was registered. To test the response to flight of the insects, the flies were gently tapped to the bottom of a glass flask. After 30 seconds, the numbers of flies remaining in the base and in the top of the flask were counted.

\section{Biochemical measurements}

Flies were homogenized in $0.1 \mathrm{M}$ phosphate buffer $\mathrm{pH} 7.0$ and centrifuged at $1000 \mathrm{~g}$ for 5 minutes $\left(4^{\circ} \mathrm{C}\right)$. The supernatant was isolated and an aliquot separated for determination of acetylcholinesterase activity, glutathione and hydroperoxide content based on protocols previously described (Franco et al., 2009). The remaining supernatant was then centrifuged at $20,000 \mathrm{~g}$ for 30 minutes. The resulted supernatant was used for determination of glutathione S-transferase (GST) and catalase (CAT) activity according to methods described earlier (Franco et al., 2009). 

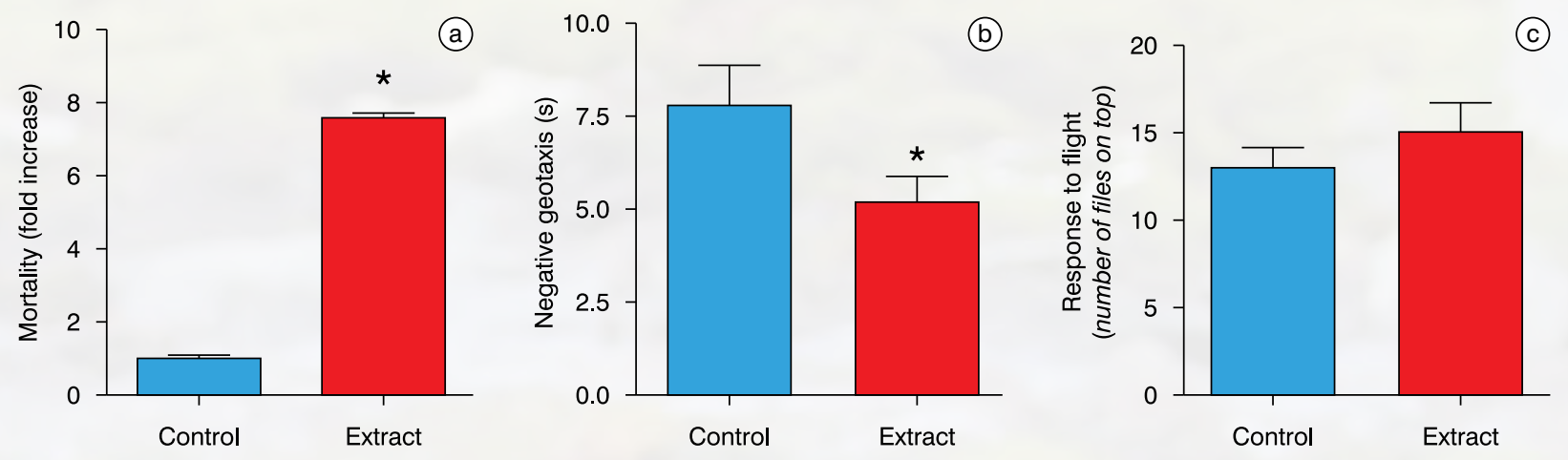

Figure 1. Drosophila melanogaster mortality and behaviour after treatment with Prasiola crispa extract. Flies were treated for 24 hours with 2 mg/mL. After treatment, (a) mortality was observed for a period of 24 hours. Surviving flies were used for determination of (b) negative geotaxis behaviour and (c) response to flight. Statistical significance was assessed by Student's $t$-test. ${ }^{*} p<0.05$.

Table 1. Enzyme activities, glutathione and hydroperoxide levels.

\begin{tabular}{cccccc} 
& $\begin{array}{c}\text { AchE } \\
\text { (mU/mg protein) }\end{array}$ & $\begin{array}{c}\text { GST } \\
\text { (mU/mg protein) }\end{array}$ & $\begin{array}{c}\text { CAT } \\
\text { (mU/mg protein) }\end{array}$ & $\begin{array}{c}\text { GSH } \\
\text { ( } \boldsymbol{\mu m o l} / \mathbf{m g} \text { protein) }\end{array}$ & $\begin{array}{c}\text { Hydroperoxides } \\
\text { (nmol/mg protein) }\end{array}$ \\
\hline Control & $30.1 \pm 5.0$ & $92.9 \pm 15.5$ & $159.4 \pm 8.3$ & $0.20 \pm 0.03$ & $0.26 \pm 0.001$ \\
Extract & $27.2 \pm 0.4$ & $141.1 \pm 13.3^{*}$ & $128.2 \pm 12.8^{*}$ & $0.23 \pm 0.001$ & $0.24 \pm 0.004$ \\
\hline
\end{tabular}

Statistical significance was assessed by Student's $t$-test. ${ }^{*} \mathrm{p}<0.05$.

\section{Results}

Treatment of flies with $2 \mathrm{mg} / \mathrm{mL}$ of Prasiola crispa extract resulted in a substantial increase ( 7.6 fold increase, $p<0.05$ ) in mortality after 24 hours (Figure 1a). An increase in neurolocomotor activity, assessed by negative geotaxis behaviour was also observed. In this task, flies that received algae extract were significantly more efficient $(p<0.05)$ in climbing performance (Figure 1b). Fly response was not altered by algae extract administration during 24 hours (Figure 1c).

Acetylcholine esterase activity (AchE), glutathione levels (GSH) and hydroperoxide formation (LPO) was not changed after Prasiola crispa extract administration to Drosophila melanogaster for 24 hours (Table 1). However, it was possible to observe a significant increase $(p<0.05)$ in glutathione S-transferase (GST) activity while catalase (CAT) was significantly inhibited $(p<0.05)$ in flies treated with $2 \mathrm{mg} / \mathrm{mL}$ of algae extract (Table 1 ).

\section{Discussion}

Commercial insecticides and repellents with lower mammalian toxicity are desirable and studies focusing the search for novel biopesticides are ongoing. In the present study, we investigated the potential insecticidal action of an Antarctic algae extract. It has been reported that plant derived compounds may pose toxicity to a wide range of insects including flies and cockroaches (Kiran et al., 2007). Plant derived chemicals such as terpenoids and flavonoids have been studied for their insect repellent activity as well as antimicrobial action (Bell et al., 1990; Ndemah et al., 2002). Our results demonstrated that exposure of fruit flies to a $2 \mathrm{mg} / \mathrm{mL}$ solution of Prasiola crispa, for 24 hours caused signs of toxicity related to disruption of neurobehavioural function as well as important cell defence antioxidant systems. Treatment of flies with algae extract caused a massive increase in mortality. This effect was accompanied by changes in negative geotaxis, a commonly used behaviour addressed to assess neurolocomotor function in Drosophila melanogaster. This result suggests that Prasiola crispa extract toxicity may be related to a potential interaction of phytochemicals derived from this plant with neurotransmission systems involved in the regulation of such behavioural task. 
Glutathione S-transferase is an important antioxidant enzyme and is involved in phase II detoxification systems (Sau et al., 2010). The observed increased GST activity in Drosophila melanogaster exposed to Prasiola crispa extract may be related to an adaptive response related to an increased elimination of toxic plant derivatives. The inhibition of CAT activity may also be an important mechanism of toxicity of the extract, since this enzyme has a crucial role in the clearance of hydrogen peroxide from cells (Aebi, 1984). The disruption of cell defence antioxidant systems has been pointed out as a central mechanism of action in a variety of models of investigation of drug/ compound toxicity (Franco et al., 2009).

\section{Conclusion}

In conclusion, our results show preliminary data on the insecticidal effects of Prasiola crispa extract in a Drosophila melanogaster model. The exact mechanisms of toxicity still remain to be elucidated, however, interaction with antioxidant systems may be pointed out as a clue in further studies.

This study comprehends part of the work of Brazilian researchers from the "Instituto Nacional de Ciência e Tecnologia Antártico de Pesquisas Ambientais INCT-APA" related to Antarctic plant chemistry and its biotechnological applications. It is believed that knowledge on the biotechnological potentials of Antarctic plants, in addition to research on plant/communities biology and evolving processes are essential to the preservation of these natural resources.

\section{Acknowledgements}

Authors acknowledge the "Instituto Nacional de Ciência e Tecnologia Antártico de Pesquisas Ambientais - INCT-APA", CNPq (574018/2008-5) and FAPERJ (E-16/170.023/2008).

\section{References}

Aebi, H. (1984). Catalase in vitro. Methods in Enzymology, 105:121-6.

Bell, A.E.; Fellows, L.E. \& Simmonds, S.J. (1990). Natural products from plants for the control of insect pests. In: Hodgson, E. \& Kuhr, R.J., (Eds.). Safer insecticide development and use. Marcel Dekker. USA.

Bland, N.D.; Robinson, P.; Thomas, J.E.; Shirras, A.D.; Turner, A.J. \& Isaac, R.E. (2009). Locomotor and geotactic behavior of Drosophila melanogaster over-expressing neprilysin 2. Peptides 30:571-4.

Franco, J.L.; Posser, T.; Mattos, J.J.; Trevisan, R.; Brocardo, P.S.; Rodrigues, A.L.; Leal, R.B.; Farina, M.; Marques, M.R.; Bainy, A.C. \& Dafre, A.L. (2009). Zinc reverses malathion-induced impairment in antioxidant defenses. Toxicology Letters, 187:137-43.

Golombieski, R.M.; Graichen, D.A.; Pivetta, L.A.; Nogueira, C.W.; Loreto, E.L. \& Rocha, J.B. (2008). Diphenyl diselenide [(phse)2] inhibits Drosophila melanogaster delta-aminolevulinate dehydratase (delta-ala-d) gene transcription and enzyme activity. Comparative Biochemistry and Physiology - Part C: Toxicology \& Pharmacology, 147(2):198-204.

Jimenez-Del-Rio, M.; Guzman-Martinez, C. \& Velez-Pardo, C. (2010). The effects of polyphenols on survival and locomotor activity in Drosophila melanogaster exposed to iron and paraquat. Neurochemical Research, 35(2):227-238.

Kiran, S.R.; Devi, P.S. \& Reddy, K.J. (2007). Bioactivity of essential oils and sequiterpenes of Chloroxylon swietenia DC against the Helicoverpa armigera. Current Science, 93:544-8.

Mostaert, A.S.; Higgins, M.J.; Fukuma, T.; Rindi, F. \& Jarvis, S.P. (2006). Nanoscale mechanical characterisation of amyloid fibrils discovered in a natural adhesive. Journal of Biological Physics, 32(5): 393-401.

Ndemah, R.; Gounou, S. \& Schulthess, F. (2002). The role of wild grasses in the management of lepidopterous stem-borers on maize in the humid tropics of Western Africa. Bulletin of Entomological Research, 92(6): 507-19. 
Pereira, B.K.; Rosa, R.M.; da Silva, J.; Guecheva, T.N.; Oliveira, I.M.; lanistcki, M.; Benvegnu, V.C.; Furtado, G.V.; Ferraz, A.; Richter, M.F.; Schroder, N.; Pereira, A.B. \& Henriques, J.A. (2009). Protective effects of three extracts from antarctic plants against ultraviolet radiation in several biological models. Journal of Photochemistry and Photobiology B: Biology, 96(2):117-29.

Sau, A.; Pellizzari, T.F.; Valentino, F.; Federici, G. \& Caccuri, A.M. (2010). Glutathione transferases and development of new principles to overcome drug resistance. Archives of Biochemistry and Biophysics, 500(2): 116-22.

Sujatha, S. (2010). Essential oil and its insecticidal activity of medicinal aromatic plant Vetiveria zizanioides (L.) against the red flour beetle Tribolium castaneum (Herbst). Asian Journal of Agricultural Sciences 2(3):84-8. 